\title{
From the traditions of J-horror to the representation of kakusa shakai in Kurosawa's film Tokyo Sonata*
}

\author{
ROMAN ROSENBAUM
}

\section{Abstract}

This article investigates the popular cultural implications of the "gap-widening society" (kakusa shakai) as identified by Yamada Masahiro. A recent revival of sociological terms like freeter and NEET in popular cultural media reflects an increasing concern with the rapidly changing social landscape in contemporary Japanese society. Starting with the phenomenon of postwar economic growth, each subsequent generation of Japanese has allegorically and symbolically represented the dramatic social changes they experienced through popular cultural media like film and manga.

This article also examines how Japan's growing stratification is situated within the popular cultural media of recent films. Special consideration is given to the plight of Japan's older working-class generations who are profoundly affected by the accelerating kakusa shakai trend of recent years. This concern is especially evident in the film Tokyo Sonata directed by Kurosawa Kiyoshi in 2008, which depicts a family in crisis because of the traditional breadwinner losing his job. In comparison, Tanada Yukis Hyakuman-en to nigamushi onna [One million yen and the nigamushi woman ], which was also published in 2008, depicts the contemporary social challenges of the much younger freeter generation upon graduating from university. The aim of this investigation is to gauge how the current discourse on Japan's "gap-widening society" is encoded in recent literature and films.

Keywords: shomin-geki; realist film; working class; kakusa shakai; social disparity; Japanese film; Kurosawa Kiyoshi.

\section{Introduction}

I initially dismissed the idea of portraying an average family as being very static, but I think that what I realized was that everybody, though they belong to a family, they go out [sic] into the 
world. So, if you think about it, every one of them confronts their own set of problems and issues out in the world - and then they bring those back home, into the family. So I found that the family drama really had the potential for a real dynamic space for all these forces colliding.

(Kurosawa in a conversation with Kasman [17 October 2008])

This statement by writer-director Kurosawa Kiyoshi $(* 1955)$ marks a surprise shift from his predilection for the horror genre to a focus on family drama, a shift indicative of Japan's most recent social malaise, commonly referred to as kakusa shakai [gap-widening society]. ${ }^{1}$ This paper investigates the popular cultural implications of the kakusa shakai phenomenon as identified by sociology professor Yamada Masahiro in his (2004) best-selling Kibō kakusa shakai: "Makegumi" no zetsubōkan ga Nihon o hikisaku [Society of expectation gaps: The despair of "losers" is tearing up Japan]. This book was followed by the marketing-researcher and social critic Miura Atsushi's (2005) study Karyū shakai: Aratana kaisō shüdan no shutsugen [Lower-class society: The appearance of a new class stratum]. Both books have added valuable research to the discourse on Japan's recent phenomenon of rapidly increasing socioeconomic stratification and as a result have redefined contemporary class consciousness in Japan. Kurosawa's depiction of kakusa shakai in film is striking primarily because it suggests a departure from his preferred genre of J-horror ${ }^{2}$. However, as this investigation of his latest films demonstrates, Kurosawa is not actually departing from the J-horror tradition; rather, he is transforming the quotidian experience of Japan's working class into a discourse on the abject horror of the mundane.

Kurosawa is by no means alone in what he is doing, and the tendency to refocus Japanese popular cultural discourse on the increasingly stratified Japanese landscape, with its ever-widening gap between rich and poor, is arguably one of the most conspicuous acknowledgments of the serious problems of social diversification in Japan. For a society that has traditionally regarded itself as homogeneous and classless and which took lifetime employment for granted, rapid social stratification has come as a serious blow. Aggravated by the recent global financial crisis, the repercussions of this social phenomenon may also relate directly to the victory of the relatively untested centre-left group, the Democratic Party of Japan (McDonald 29-30 August 2009).

\section{Social consciousness in Japanese film: A historical perspective}

Accompanying this transformation of the focal point in popular culture is the resurgence of terms like freeter (furit $\bar{a})$ and NEET $^{3}$ that reflect an 
increasing concern with the rapid changes in contemporary Japanese society. These sociological terms were in common use during the late 1980s and initially connoted a sense of idolisation for young people who deliberately eschewed employment despite the large availability of jobs but chose instead to pursue their dreams. However, once Japan's economic bubble began to burst in the early 1990s this adoration changed quickly and the rapid increase of freeters was re-conceptualised as one of the most disturbing social trends in the early years of the $21^{\text {st }}$ century. This re-conceptualisation is not unprecedented and, quite on the contrary, Japanese society has a long tradition of verbalising social conditions through artistic production. In particular, the encoding of proletarian motifs in film started with Japan's postwar economic revival, when popular cultural media like literature, film and manga allegorically and symbolically reflected the dramatic social changes of each specific generation. In addition, the peculiar social circumstances of a historical era, like the baby-boomer generation and the student movements in the 1960s and 1970s, were contextualised by specific modes of cinematic expression. These expressions are specific to historical eras, and early postwar films like Ozu Yasujirō's Kaze no naka no mendori [A Hen in the Wind, published in 1948) allegorically reflected the social influence of the war through a couple's troubled relationship. Similarly, Naruse Mikio's 1952 masterpiece of postwar Japanese cinema, Okāsan [Mother] symbolically retells the social hardship of the immediate postwar years through the story of a poor, working-class mother with a sick husband who sacrifices herself to support her family in suburban Tokyo. Both Naruse Mikio (1905-1969) and Ozu Yasujirō (1903-1963) were two prominent directors to work primarily in the genre of shomin-geki [i.e., realist films focusing on the working class], which depicted radically new social circumstances through the popular film media at the time. Similarly, the contemporary increase in Japan's social stratification has arguably been captured in the discursive formations of recent popular cultural representation. Following in their footsteps were the nüberu $b \bar{a} g u^{4}$ [Japanese New Wave filmmakers], who dominated the late 1950s through to the early 1970s (Desser 1988: 4-11). They were the first to openly critique the assumptions underpinning Japan's modern social structures. Working independently, the key figures of this cinema of socio-cultural exploration included Hani Susumu, Teshigahara Hiroshi, Masumura Yasuzo, Shinoda Masahiro, Ōshima Nagisa, and Imamura Shōhei. These Japanese New Wave filmmakers set themselves apart from the more traditional Japanese cinema through their depiction of such taboo topics as social outcasts (including criminals and delinquents) as protagonists, explicit sexuality, the changing social roles of women, racism, and the position of ethnic minorities in Japan. Female protagonists like Tome, in 
Imamura's Nippon konchüki [The Insect Woman, 1963), born into the lower class, and the adolescent delinquents of Oshima's Seishun zankoku monogatari [Cruel Story of Youth, 1960] were a departure from Japan's strict socio-cultural taboos on representation. Moving towards a more probing realistic style of cinematic social inquiry, nouvelle vague was the heyday of cinematic social dramatisation in Japanese cinema.

Japan's phenomenal postwar economic growth was portrayed through the rise of the salariman-geki [i.e., drama about the salaried working class], which was conspicuous until the economic bubble burst in the late $1980 \mathrm{~s},{ }^{5}$ when gendai-geki [contemporary drama] started to portray the resultant social malaise as a replacement to the shomin-geki tradition. In this context the depiction of the devastating consequences of social stratification, commonly contained within the simplistic catchphrase of kakusa shakai, on the middle-aged working class in terms of unemployment, stigmatisation, the failure of social welfare, and the lack of community support in Kurosawa's films are cognate with a form of contemporary neo-shomin-geki that raises concerns about the lives of ordinary working-class people in times of rapid social transition.

The political analyst Hamish McDonald (29-30 August 2009) has pointed out that, as of 2009, Japan has the highest government debt load of any advanced economy, at 180 per cent of its GDP. The economic stimulus packages of the former Prime Minister Aso Taro's government amounting to eight per cent of GDP have further increased the nation's financial liability. It is this legacy of the long-serving Liberal Democratic Party (LDP) that has engendered the mistrust of several directors, who have begun to portray the effect of Japan's increasing social stratification through the medium of cinema. These directors have transformed traditional genres to reflect on how this shifting stratification is reflected in popular culture. Miki Satoshi is yet another charismatic new director who works across a multitude of different genres and has refocused his creative output on a portrayal of the social malaise gripping contemporary Japan, as for example in his recent film Tenten (English festival title: Adrift in Tokyo, 2007), which depicts a freeter by the name of Fumiya, who had been a university student for eight years and owed money to a loan shark. When the loan shark, Fukuhara, comes to collect the debt and Fumiya is unable to pay, Fukuhara asks him to accompany him on a trip across Tokyo, where he will turn himself in for a crime that he deeply regrets. The ensuing archetypal journey across the landscape of Tokyo is based on a novel by the $125^{\text {th }}$ Naoki Prize winner Fujita Yoshinaga and is an allegorical rite of passage across the stratified landscape of urban Japan.

In February 2009, female director Tanada Yuki was awarded the $49^{\text {th }}$ Association of New Japanese Film Directors Prize (Nihon eiga kantoku 
kyōkai shinjin-shō) for her accurate portrayal of the difficulties faced by the younger generation in Japan's stratified society. Similarly selfreflective, Tanada Yuki's Hyakuman-en to nigamushi onna [One million yen and the nigamushi woman, 2008] depicts a female freeter, Suzuko, who, after spending some time in prison for a misdemeanour, is faced with gossip and family conflict. Rather than dealing with these issues, Suzuko decides to wander from place to place, leaving whenever she has saved one million yen. This metaphor for the casualisation of the Japanese workplace predicates the avoidance of confrontation, postponement and transient rootlessness as the central motif of the movie.

Both Tenten and Hyakuman-en to nigamushi onna are remarkable because they distance themselves from the stereotypical depiction of freeters as "parasite singles" or "young unmarried people who chose to live with their parents, even after graduation, to save money" (Yamada 1999: 11), that is, people who rely on the older generations to support them. On the contrary, both movies endow the main protagonists with a surprising wanderlust to go out and express themselves in the world, even though this is done in an exceedingly quirky way. They also deal directly with the social integration of a generation of young adults essentially disenfranchised from the contemporary social structure and depict the tensions between the generations. These films are important portrayals of the effects of kakusa shakai on Japan's younger generation and set the tone for the recent interest of the Japanese film industry in Japan's rapidly changing social landscape. However, it is Kurosawa Kiyoshi's latest film, Tokyo Sonata that has extended this concern to Japan's salaried baby-boomer generation in a powerful allegory on the demise of the nuclear family in Japan.

This extension of the kakusa shakai motif into the realm of the nuclear family is important because it creates a cross-generational as well as cross-gender discourse which suggests that all aspects of contemporary Japanese society are affected by the social ramifications of a rapidly stratifying society. For Japan's older generations, Tokyo Sonata is about the crisis confronting Japan's nuclear family, because the traditional breadwinner has lost his job. The drama of the nuclear family unfolding against the backdrop of unemployment highlights an increase in social stratification in contemporary Japan, especially in its large and until now stable middle class of salaried middle-aged employees who are used to Japan's economic tradition of shüshin koyō [lifetime employment].

\section{Kurosawa Kiyoshi: Towards a filmography of kakusa shakai}

Anyone in the film industry with the name Kurosawa, even if not related to the enigmatic Kurosawa Akira (1910-1998), is bound to be noticed. 
However, while Kurosawa Kiyoshi is perhaps best known for his many contributions to the psychological J-horror genre, which have earned him nicknames like "Godfather of J-Horror" and Japanese "horror maestro," there is also in his work a long history of portraying the social consciousness of his famous predecessor, culminating in 2008 with his tour de force film Tokyo Sonata. Arguably, Kurosawa's horror movies have reflected the deep angst of a Japanese society that values group participation and acquiescence over individual identity. His definition of horror makes the connection between his horror movies and his more recent socially engaging films apparent:

I don't think that blood spurting or screaming instigates abject human fear. They may be shocked, but this doesn't lead to pure terror. What I consider a genuinely effective horror film is that well after the film is over and the audience has gone home, the fear and terror instilled in them survives. (Kurosawa in an interview with indie WIRE [Mottesheard 1 August 2001)]

Kurosawa's notion of horror and angst goes far beyond superficial thrills and entertainment towards a more psychological and innate sense of torment that readily encompasses the social malaise of abandonment, disillusion, and fragmentation experienced by contemporary Japanese society. Kurosawa first began directing in the 1980s, working on lowbudget V-Cinema (i.e., direct-to-video) productions such as formulaic films about the Japanese Mafia (yakuza eiga). In the early 1990s, he won a scholarship to the Sundance Institute that enabled him to study film making in the United States, although by then he had already been directing professionally for nearly ten years.

Kurosawa has now become by popular consent the first major Japanese filmmaker to emerge since Kitano Takeshi and is riding the crest of the latest nouvelle vague. Gradually, Kurosawa's oeuvre has evolved from working within what he refers to as the kikai eiga domain or "mystery movies rooted in the Japanese kaidan tradition of ghost and horror stories" (Kurosawa 1992: 156), with their penchant for psychological tension, to the depiction of the horrendous banality of a quotidian working-class existence. Even more conspicuous is his transition from the J-horror genre to the much more serious socio-cultural discourse on the contemporary nuclear family of his latest film, where the dark undercurrents of kakusa shakai, subliminal in his horror movies, abruptly bubble to the surface in an upsurge of social tension. It was not until the release of $K y u \bar{a}$ [Cure] in 1997, which depicts a wave of gruesome murders in the capital by a young master hypnotist, that Kurosawa achieved international acclaim. He has acknowledged that a common theme in his 
films is cataclysmic events that shatter the value system of his protagonists and utterly undermine their sense of self:

To elaborate on that, I would say my characters have had their value system shattered, but by film's end, wind up with an altogether different value system. Living in the democracy that is modern-day Japan, I am told I am quite free to do what I want. But I think in fact, I am bound by common practice, laws and accepted morality, so I don't feel very free at all. So in that sense, while I may be incapable of cutting myself free from all these ties that bind me, in my fictional stories, I take a fictional character bound by all of these conventions and allow them an opportunity to break free. They can walk towards what, until then, had been an unfathomable freedom. (Mottesheard 1 August 2001)

Freedom in Japan is a complex concept that Kurosawa elaborates upon in the semi-sequel gothic horror Karisuma [Charisma, 1999], in which a poisonous tree becomes an allegory for the structure of Japanese society and the tension between the importance of the individual on the one hand, and the group on the other. This was followed by Kairo [Pulse, 2001], whose central plot revolves around a ghost invading the world of the living via the Internet. Kairo is a philosophical exploration of the alienation and loneliness of modern existence thanks to technology and, more specifically, the Internet.

Communication breakdown and isolation followed by the search for a new identity are the main themes in Kurosawa's oeuvre. Moving gradually from supernatural horror to verisimilitude, Kurosawa began his engagement with the adverse affects of social stratification and its impact on the lives of young Japanese already in 2003 with the satirical Akarui mirai [Bright future], in which he adopts the drifting life of a jellyfish as a powerful metaphor for Japanese youth gripped by anomie. Essentially a tale about social engagement between the well-established generation of the older working class and the much younger generation of Japan's furita $\bar{a}$, the film comments on the deregulation of Japan's employment protection laws in 1999. Instituted during the unpopular stewardship of Prime Minister Mori Yoshirō, this deregulation saw a huge shift by 2008 from full-time permanent jobs, with those in contract and part-time work at 33.5 per cent of the workforce (McDonald 29-30 August 2009). It is fair to say that all of Kurosawa's films are concerned with the way contemporary society moulds the individual psyche into something unprecedented. Kurosawa reframes individuals that are subsumed by the conglomerates of consumers, trapped in-between the hegemony of tradi- 
tional Japanese self-effacing social obligation and a postmodern capitalist society, into something that lies between the horror of the past and the angst for the future.

\section{Generational perspectives of kakusa shakai}

One of the most pervasive postwar social myths was that ninety per cent of Japanese society is a middle-class social stratum without distinct class differentiation. Yet, with the recent polarisation of society into extreme winners and losers, this last contradiction of the homogeneity debate has been debunked and dismantled, with devastating consequences. For example, under reforms advanced by Koizumi Junichiro from 2001 to 2006, a large proportion of Japanese employees were subjected to both a wages squeeze and growing job insecurity, without much effort being made to erect a welfare safety net (McDonald 29-30 August 2009).

The political reforms introduced by Mori and Koizumi gradually shifted Japanese labour reform from the domestic protectionism of paternalistic socialism to a freer market-driven competitive capitalism. Suddenly, the company as a paternal institution with its promise of lifelong employment could no longer look after its "children" as is depicted in the very first scene of Tokyo Sonata, in which the company abandons its children (i.e., its middle-aged salaried employees) in favour of a younger and much cheaper workforce located overseas, so that suddenly the all-powerful head of the family (i.e., the breadwinner and patriarch) himself is no longer able to look after his own children. The metaphor for the breakdown of the nuclear family extends to the all-important eldest son (chōnan), who eschews his responsibility and leaves the country instead of fulfilling his traditional role of continuing the bloodline and inheriting the family estate.

It is no coincidence that this instability arising from increasing social stratification in contemporary Japan has been most keenly rendered by both filmmakers and artists in general, who belong to what has been referred to as the disenchanted generation (shirake sedai ${ }^{6}$. This generation attended high school after the end of the Korean War during a time when the sharp rise in the birthrate of the baby boomers had ceased and the Japanese postwar economic miracle (kōdo keizai seichō) began to subside. Just like his favourite actor Yakusho Koji, who plays the pivotal role of a burglar in Tokyo Sonata, Kurosawa was born in 1955, into a generation destined to become disillusioned with the establishment. $\mathrm{He}$ explains their cooperation in the following way: "He's [Yakusho Koji] exactly the same age as me. He's not only easy to work with as an actor, but he's very similar to me as a person. He has similar values and sensitivities. We're from the same generation" (Kurosawa in an interview 
with Erickson [3 December 2009]). The "values and sensitivities" Kurosawa refers to here are their common disillusionment with the political and social status quo of contemporary Japan arising from their shared generational apathy. Yakusho is Kurosawa's own projection of his cinematic alter ego and thus filmmaker and lead actor share the same childhood experience of a Japan in rapid transition.

The shirake sedai is concerned with the social problems caused by an ever-increasing number of freeters, or young people who hop from one unskilled part-time job to the next with little chance of building a career, because social disparities (kakusa shakai) are polarising all aspects of contemporary Japan. Similar to the neo-realism of the New Wave cinema of the 1960s, Kurosawa's migration to socially engaged cinema signifies the emergence of a contemporary new-wave movement in Japan.

\section{Tokyo Sonata}

In 2008, Kurosawa focused on the effects on an ordinary nuclear family of Japan's long-term post-bubble recession. Whereas in his previous films he expressed concern in an abstract way about the evolving Japanese identity, in Tokyo Sonata he has discarded the metaphorical supernatural and mythical themes in favour of a heightened sense of realism. With this, his films have moved from the allegorical representation of a supernatural, mythical "outsider" and social outcast to the realistic portrayal of the kakusa shakai phenomenon, which connects his films to the Japanese cinematic tradition of realist films focusing on the working class (shomin-geki). I argue that his "coming out" of the metaphorical mode of expression into the realm of realism exemplifies the dire straits Japanese society finds itself in; there is no longer room for roundabout modes of expression. Tokyo Sonata is about what it feels like to live in a society undergoing massive, disorienting changes that are attacking the very essence of idealised Japanese identity.

As such, Tokyo Sonata is a horror movie stripped of any gratuitous gore and violence; quite to the contrary, its horror is psychological and real. The film's horror consists entirely of the mundane, monotonous everyday alienation suffered by Japan's stereotypical nuclear family: the insensitive father-son relationships, the huge gulf between husband and wife, and the boring repetitive nature of human relations devoid of communication and kinship amidst the robotic landscape of Japan's working-class drones.

Kurosawa's grotesque depiction of Japan's disenfranchised working class is remarkable, not only because it is a departure from the J-horror tradition, but also because of its originality, presented as it is in the guise of a startlingly rich, funny, and strong drama without a hint of the el- 
dritch or occult. The head of the nuclear family, Ryūhei, played by Kagawa Teruyuki, is a chief administrator in a medical-supplies company. $\mathrm{He}$ is told by his manager that the company is going ahead with a plan to move its administration department to Dalian in China. This outsourcing eventuated from the fact that three Chinese nationals can be hired for the wage of one Japanese employee. Calling the long-serving Ryūhei into his office, the manager declares that he has done a great job as director of administration before asking as if in passing, "What will you do after you leave administration?" This is the opening scene of the film and the implications of the question leave viewers as stunned as the main protagonist.

Shortly after Ryūhei realises that he is being made redundant, he is asked: "What are your skills?" In response to this indignity, he simply leaves without a word. This scene is antithetical to the Americanised catchphrase "you're fired" popularised by Donald Trump's reality TV show The Apprentice, where unsuccessful contestants were successively "fired" and eliminated from the game. The phrase was repeated the world over during the recent global financial crisis (sekai kinyu kiki), which also hit hard in Japan. The implications are much more subtle and in Tokyo Sonata throughout the film Ryūhei is continually forced to explain what he can bring to a job. Unfortunately, when put on the spot during a job interview, all he can think of is karaoke. In the end, he joins the diaspora of the unemployed and downsized, loitering in parks around Tokyo. He is unable to tell his wife, Megumi (played by Koizumi Kyoko), which comes as no surprise since their communication has been reduced to monosyllabic and hackneyed phrases devoid of any real meaning. It is not much better with his sons, Takashi (played by Koyanagi Yū) and Kenji (played by Inowaki Kai), who lead separate lives, crossing paths only fleetingly at the dinner table. Playing out his patriarchal role, Ryūhei continues to dress for work, leave in the morning and go to the park in search of employment. It all comes to a head when out of the blue his eldest son approaches his father to sign a document so that he can join the military:

Takashi: I want you to sign these papers.

Ryūhei: I absolutely forbid it.

Takashi: Why?

Ryūhei: I raised you so you could lead a happy life. This couldn't be farther from that goal.

Takashi: But in the military, you can work for peace.

Ryūhei: That's just rationalising.

Takashi: But it's true; why should I alone be happy? It's better to make the whole world happy. 
Ryūhei: The whole world? What's that? Who cares about that? I'm not worried about the world, I'm worried about you.

Takashi: That's why Japan's so hopeless. It's the American military that protects Japan.

Ryūhei: So what?

(Kurosawa, Tokyo Sonata, 2008: 00:48:56-00:50:12).

Ryūhei's eldest son, the all-important eldest son (chōnan) who must continue the bloodline of the family, is disillusioned with Japan. The dialogue quoted above is indicative of the attitude of Japan's younger generation, increasingly disenfranchised by reforms that have led to a dramatic polarisation of wealth in Japan, second only to the advanced economies to the United States, with about forty per cent of male workers and more than eighty per cent of female workers earning less than 4 million yen a year (McDonald 29-30 August 2009). Kurosawa's Tokyo Sonata focuses squarely on the lower socio-economic class, the former middleclass salaried employees, who unexpectedly find themselves homeless, with squatter settlements growing in most metropolitan areas. It also vividly portrays the governmental unemployment and income-support agencies that simply do not have the budget to pay benefits to the growing numbers of people entitled to them. It is against this backdrop that Takashi leaves the family to serve in the army and thus begins the rapid breakdown of the nuclear family in Kurosawa's film.

The struggling nuclear family and their desire for "starting over again" (yarinaoshi) is central to the plot of Kurosawa Kiyoshi's Tokyo Sonata. After Ryūhei has abruptly lost his position, with its assurance of lifetime employment, he conceals it from his family. And his youngest son, Kenji, misappropriates his lunch money to furtively take piano lessons from a dedicated piano teacher (played by Igawa Haruka) against his father's wishes. By depicting the weaknesses and faults of each male member of the family, Kurosawa undermines the very notion of Japanese masculinity. Yet even the conventional mother figure, Megumi, the stereotypical obedient wife and mother and a reminder of Japan's tradition of the "good wife, wise mother" (ryōsai kenbo), struggles to keep the family together. Following a domestic dispute, she reveals to her husband that she saw him in a food queue in the park and knew all along that he was unemployed. Ryūhei is astounded and asks her why she did not say anything to him. Here, Kurosawa points to the paradox of contemporary Japan, where homogeneity - in the workplace, home and society at large - is nothing but a charade, an illusion that displaces the real social circumstances of the widening social gaps in Japan. In an interview, Kurosawa has confirmed that once again the lack of dialogue between the family members is a reflection of Japanese society at large. 
A rift has somehow developed within the family, spreading quickly and quietly, and threatening to break them apart (Guillen 4 December 2008).

It may seem somewhat incongruous for a filmmaker working predominantly in the horror genre, but Kurosawa's family drama manages to portray the humanity of disenfranchised people in a funny, uplifting way without being patronising. Kurosawa's message is clear: bureaucrats and politicians are only partly to blame for this mess and it is the pervasive malignant apathy in Japanese society that is really responsible for the social malaise inherent in kakusa shakai. The sense of apathy (mukanshin) in Tokyo Sonata creates a sense of angst not unlike that generated by the malignant supernatural miasmas in his horror films. Yet this time, the antidote is the active involvement of individuals in society. Kurosawa's message to get involved is clearly directed towards all members of the nuclear family, young and old, but in particular to his own shirake [disenchanted] generation, who failed to follow in the footsteps of the yakeato [burnt-out ruins] generation. It was the yakeato generation that was directly exposed to the horrors of the Asia-Pacific War who fought actively for social involvement.

As far as Kurosawa is concerned, humanity is to be found in the interstice between horror and humour, the polarised tensions acting on his lead characters not unlike the rich/poor dichotomy that is beginning to divide Japan. While Ryūhei is forced to clean toilets in fancy department stores, Megumi indulges her fantasy by going window shopping for a luxury car. When Ryūhei discovers a large stash of money in one of the toilets, his sense of justice is pushed to the extreme and he simply runs away with the money. The tension finally culminates in a night of extreme trauma during which each family member undergoes a transformative experience in order to begin the healing process. As he flees the department store with the money in his pocket, Ryūhei is struck by a car and left unconscious in the street, likened to the garbage in the streets.

Yet Kurosawa's discourse on kakusa shakai also engages his female audience. Returning from her shopping spree, Megumi is subjected to a break-in by a derelict looking for cash (played by award-winning actor Yakusho Kōji). The hapless thief takes her hostage but sets her free when she willingly returns after going to the toilet. She refuses to leave, however, and follows him to his ramshackle abode by the sea, the ensuing sexual encounter between two characters drawn to the edge of society reinvigorating her. Even the youngest generation is affected by the repercussions of the dramatic social changes occurring all around them and while the older son, Takashi, is serving overseas in the military, the younger son, Kenji, is arrested for fare-evasion while trying to sneak into the baggage compartment of a bus, ostensibly to run away from home. Since 
he refuses to reveal his identity he is put in a cell with adult criminals. Eventually his charges are dropped and the family reunites in their home after a night of madness and transition. Even the traditional homestead is precariously perched on a major train line, marking its place only as a transitory portal into the social world of Japan. Individuals meet at the home, but ultimately it is our action or non-action in society that determines our status in society. The peace and harmony of the traditional hearth is an illusion in the contemporary global consumer society, where we are only as much as we strive to be.

Tokyo Sonata ends ambiguously; nothing is magically resolved. Yet there is a new sense of harmony as each character resumes their role in society. The increasing polarity of Japanese society with its ups and downs did not succeed in destroying this family. It came precariously close, though, and it is only after they have accepted responsibility for their roles that things apparently return to normal. Ryūhei returns the money he found, Megumi resumes her role as the obedient mother, and Kenji and Takashi return home to reunite at the dinner table. Arguably, this is where the film also disappoints most prominently, because, watching them eat in silence, we know that things have not really changed. The only dramatic change is provided in the final scene, where Kenji is playing the piano in an entrance exam to a special school for gifted children. Once again society is idealised, miracles happen and difficulties evaporate miraculously. As we listen enthralled to the final sonata, played expertly by the child prodigy Kenji, we are filled with hope arising from the healing power of music. It is in the transcendent qualities of the next generation where Kurosawa locates the answer to the extreme effects of Japan's increasing polarisation on the traditional family unit of Japan.

But all is not lost, and it is the possibility of regeneration that Kurosawa highlights in Tokyo Sonata, especially in the stereotypically stale relationship between husband and wife, which for once is given a new chance by the dramatic change in social circumstances, as are the fatherson relationships, worn thin by years of disengagement and lack of communication. Stepping outside our comfort zones and actively engaging with the "horror" that besets our existence, appears to open up new possibilities for a renewal of family vitality.

\section{The allegorical horror of kakusa shakai}

In an interview with Daisuke Wakabayashi, Kurosawa confirms that his overriding concern in making the film was the traditional Japanese family: 
It has been crumbling little by little for many years now. The problem is that people don't have a better alternative. There is very little communication between the father and the children. No one states what they are thinking and they assume the others know what they are feeling. If you don't say anything to each other, it just leads to more alienation. (Kurosawa in an interview with The Wall Street Journal [Wakabayashi 7 March 2009])

This breakdown of the Japanese traditional family is the abject horror Kurosawa strives to describe. In his films Kurosawa suggests that this breakdown comes about internally, due to a lack of communication and the resulting alienation of the family members, and externally, through the pressures of kakusa shakai with its ramifications of joblessness and the accompanying drop in social status. It is the resulting social dilemma that replaces the explicit angst of Kurosawa's earlier horror films with a new sense of ambiguous horror that is essentially implicit and hard to pinpoint. All we know is that we are afraid and scared. Therefore, rather than being a total departure from Kurosawa's offerings in the horror genre of the past ten years, Tokyo Sonata could be his most frightening film to date. Thematically, it outlines many of the concerns relating to kakusa shakai that are also endemic to the director's horror films: loss of identity, alienation in contemporary Japanese families, the fragility of Japan's social fabric, as well as the inability to communicate and articulate our fears.

The horror genre, it appears, is particularly popular in Japan and Kurosawa has used his legacy in this genre to successfully portray the horror inherent in the dramatic social changes besieging the family in contemporary Japanese society. In her investigation of critiques of the film, Taubin (2009: 79) discerns that "the film would seem to be a turning point for Kurosawa; the sustained quiet anxiety that pervades the early scenes and the eruption of hysterical behaviour toward the end are grounded in realism with no reference to the paranormal phenomena that have been at the centre of his work." Matt Riviera, on the other hand, sees Tokyo Sonata in terms of a dystopia, suggesting that "the eruption of the supernatural - or even the semblance of the supernatural - frees men and women from their responsibilities and renders meaningless the rules that ordinarily keep them in line" (Guillen 4 December 2008). In a sense both critics are correct, but they have missed the subtle ambiguity between the alleged absence of the supernatural and the implicit malignant horror of kakusa shakai. The implications of the terrible things happening to the structure of the family place the film in-between the literary conventions of horror and realism resulting in a bricolage of magic realism. 
Yet the central theme of the film is clear: it is the unchecked stratification of a Japanese society in which the myths of homogeneity and classlessness have been the hallmarks of a Japanese identity that has led to disillusionment on an unprecedented scale. The fallout from Japan's social fragmentation is most evident in the recent political turning point that saw the end of the long rule of the LDP and the election of the DPJ. The other pressing issue adding to the difficulties posed by social polarisation is Japan's dramatic demographic slide. Hamish McDonald (29-30 August 2009) observes that Japan's population has started declining from a peak of 128 million in 2005 and could fall as low as 85 million by 2050 . The proportion of over-65-year-olds is shooting up, from twelve per cent in 1990 towards a projected thirty per cent in 2025, while children now make up only about thirteen per cent of the population, compared with thirty five per cent in the 1950s. Tokyo Sonata's sociological message is that the approaching grey society, with its high level of urbanisation and large population, should encourage people to stay longer in the workplace rather than allowing the current trend of retrenchment and outsourcing to continue.

It is because of this socio-political message, targeting Japan's disproportionally large salaried middle class, that Tokyo Sonata has received a surprising degree of international recognition and won several coveted awards. Reflecting its ambiguous reception, it was selected in 2008 in the "Un Certain Regard" category at the International Cannes Film Festival and was awarded the Jury Prize. This award category is designed to encourage innovative and audacious works by presenting films selected with a grant to aid distribution in France. It also received the award for best picture (sakuhin-shō) as well as the award for best script (by director Kurosawa Kiyoshi) at the third Asia Film Awards in Hong Kong held on 23 March 2009.

Kurosawa goes to great lengths in depicting the social horror of the male gender role and Japanese myths about stoic masculinity in contemporary patriarchal Japanese society. It is in Tokyo Sonata that his dialectic on the traditional family unit climaxes in an attempt to redefine masculinity in the post-salaryman era. Despite his supposedly dominant role as the head of the family, Ryūhei is unable to tell his wife and children that he lost his job. He is not alone and joins a diaspora of unemployed family men who are unable to confront their wives some of whom keep up the charade for years. Yet, the ever present subliminal spectre of horror briefly surfaces when a close friend of Ryūhei's who also lost his job and deceived his wife, unexpectedly commits family suicide ( $i k k a$ shinjü). Balmain (2008: 128-129) has demonstrated that, with the demise of company-directed self-sacrificial loyalty, the shift from "salary man" to "family man" in the J-horror tradition has left some men of the 
older generation feeling stranded and many younger men feeling confused about what is expected of them. It is in Kurosawa's latest film that a critique of the postwar mode of the postmodern, or in Timothy Iles' words (2008: 123) the "postindividual," form of identity finds its most consistent expression and where characters struggle most desperately against the overwhelming commodification of their selves. Tokyo Sonata is Kurosawa's attempt to portray an emerging Japanese identity as it functions within the contemporary kakusa shakai paradigm. According to Iles, this Japanese identity "in the globally proposed, politically motivated consumerist agenda is a contradictory arrangement of fashionconsciousness and atomised alienation against which urban individuals have little ability to resist, and into which they have little option but to fall" (Iles 2008: 133).

It is because of this phenomenon of de-individualisation and the loss of traditional family values in urban Japan that Kurosawa has shifted his film settings from J-horror to the urban family drama. Horror, it appears, is the most accurate mode of expressing the contemporary state of the Japanese nuclear family. Yet this is certainly not the first time that Japanese social structures like the family and, by metaphorical extension, the nation as Japan's largest family entity, have experienced a cinematic assault. Postwar cinema's predilection for giant monster films (daikaijū eiga) and their apocalyptical visions symbolise a complex cycle of social decline and renewal. It is not too difficult to see the allegorical reference to the paradigm shift triggered by Hiroshima and Nagasaki which is followed by the dramatic ideological change from militarism to democracy. Following the first wave of apocalyptic horror visions in Japan's postwar period of rapid socio-economic growth, the contemporary J-horror genre represents an extension of this thematic wherein supernatural apocalyptic conceits are employed to foreshadow a transformation of Japanese socio-political and cultural borderlands. This is also evident in Kurosawa's surprising transition from the occult horror to Tokyo Sonata. Curiously, the very destructive nature of horror and its debilitating function in film becomes a paradoxical force of renewal. Not unlike the calm after a disastrous storm, the aftermath of climactic horror creates a space for renewal and transcendence with the possibility of a metaphorical rising of the phoenix from the ashes of a devastating experience. This is also evident in Kurosawa's Tokyo Sonata, where, after each family member has been pushed to the brink of their existence, a strange equanimity reunites the family and introduces a new sense of beginning. Ryūhei accepts his youngest son's love for playing piano, the elder son returns home from military service overseas, and husband and wife start over again. 
The point here is that, although at first glance many of Kurosawa's films appear apocalyptic and bleak, paradoxically they offer the possibility of renewal from a tabula rasa; in his own words, "Many people construe those images and ideas as negative and despairing, but I actually see them as just the opposite - as the possibility of starting again with nothing; as the beginning of hope" (McRoy 2007: 137). This is again exemplified in the final scene of Tokyo Sonata where, after each family member has experienced apocalyptical trauma, leaving them in a trancelike cleansed state of awareness, there is a new sense of hope, expressed through the younger son, Kenji, playing the third movement of Claude Debussy's Suite Bergamasque, entitled "Clair de Lune".

In fact, the paradoxical message and the essence of Kurosawa's present-day family epic is that despite the bleak outlook for the Japanese nuclear family, with today's youth represented by the stereotypical categories of freeter and NEET, a ray of transcendental hope shines through:

I feel that something is drastically changing now, not only in Japan but in the bigger world. Although many things are unstable and confusing, when I talk to the young people in the university that I teach, I feel that they are very solid. I think that they are not such weakly-minded guys [sic] as people tend to label them. Particularly in Japan, youth are much more hopeful than the adults. The future for them, however, is very different from what we adults imagined in the past as an ideal future. They have this different vision and they are making an honest effort to reach it. (Kurosawa in an interview quoted by Kaifu [29 March 2009])

In other words, for Kurosawa, Japan's present young generation, caught up in kakusa shakai, is far from helpless; quite the contrary, it embraces a different value system for their future ambitions. In Tokyo Sonata this inter-generational gap is contextualised succinctly in the clash between Ryūhei's outmoded patriarchal male values and his son's new vision of seeing contemporary Japan. Even though he is engulfed by society's rapid transformation, he is unable to understand his son's new generation and his violent reaction only alienates them. Iles (2008: 106) has argued that in popular culture a tangible change has occurred in the past twenty years in the way our social identity - in works of horror, thrillers, and suspense - is contextualised. Iles singles out Kurosawa's oeuvre as the torchbearer for this change in cinematographic representational techniques. No longer is there a penchant for the supernatural monster as a source of terror and suspense that ultimately reflects our innermost fears about identity, belonging, social transformation, and national con- 
sciousness. Nevertheless, vestiges of the supernatural, like young Kenji's inexplicable piano skills, represent the enigma of the child prodigy as a representation of the occult forces displayed in Kurosawa's earlier films. In contemporary Japanese cinema, as in literature ${ }^{7}$, magic and fantastic realism have in fact replaced the supernatural as a means of expressing our innermost fears.

It is precisely because Kurosawa's protagonists conceptualise Japan's socio-economic crisis through outmoded legerdemain like supernatural powers and believe in miracles rather than active engagement, that his films still lack political and social motivation. This is one of the stumbling blocks of Kurosawa's disillusioned generation, who believe only in political motivation in the abstract:

I'm not interested in the power struggles of politicians, and I wouldn't say that Japanese youth are either, although I would say that that in itself is dangerous, because it leaves many of us open to manipulation by those very same politicians that we're not interested in. But that is not all that politics is, and I think that any time people from divergent cultures or societies encounter each other, there's always a "political" situation at work. It's this politics of interpersonal relations I'm more interested in incorporating into my films. (Kurosawa in an interview with O'Rourke [2005])

Political expression in Japanese film arguably originated in the student protest movements against the United States-Japan Security Treaty (AMPO), signed in 1951 and renewed in 1960, which symbolised the discontent of Japanese youth about the subordination of Japanese society to the United States. In films like Ōshima Nagisa's Nihon no yoru to kiri [Night and fog in Japan, 1960) about the All-Japan Federation of Student Self-Government Associations' (Zengakuren) opposition in 1950 and 1960 to the security treaties, the director dissected the social issues of political memory and the interpersonal dynamics of current social movements. According to O'Rourke (2005), it was because this film was suppressed by the studio that Ōshima became independent, like several others in the late 1960s who also worked as "auteurs" and injected into their films a social dimension. Along with Ōshima, others who created a completely new environment for protest in Japanese film were Imamura Shōhei, who also went independent, Adachi Masao, Fukasaku Kinji, Yoshida Yoshishige, and Wakamatsu Koji. It is this heritage of social engagement that Kurosawa Kiyoshi's films have taken up as far as the disillusionment of youth in contemporary Japan's kakusha shakai is concerned. 


\section{Conclusion}

Tokyo Sonata is a symbolic rite of passage for Japan's nuclear family: from the predetermined postwar discourse of the ideal family, through near destruction into a new social configuration. Kurosawa's neo-proletarian family has been severely traumatised and pushed to the brink of existence. It barely survives a series of catastrophic events befalling each member of the family. In the end it emerges, bruised and battered, from its social hiatus of conformity like the phoenix rising from the ashes. Yet Kurosawa does not provide any easy solutions but simply ends the film with the hopes and promise of the next generation. Ryūhei's younger son's desire to play the piano becomes a form of generational resistance when his father, for no apparent reason, refuses to allow him to take piano lessons even after he has been told of his son's astonishing talent. The lack of communication between father and son is yet another allegory for the nation's lack of inter-generational dialogue. Debussy's long sonata closes the film, bringing a ray of hope to the hollow ritual of family life in Japan.

Kurosawa Kiyoshi's Tokyo Sonata is a call to arms for Japan's salaried employees, who used to occupy the largest stratum of the middle class. Recent dramatic socio-economic changes have awakened this sleeping giant from political and social apathy. With lifelong employment fast disappearing and social mobility plus unemployment becoming major factors in Japanese working life, a newly emerging polarised society is having a devastating impact on the nuclear family.

The representation of the kakusa shakai in popular culture and particularly in Japanese cinema has increased dramatically in the first decade of the $21^{\text {st }}$ century. The increasing social disparities in Japan have seen the emergence of a new class consciousness, which is also reflected in literature and has led to a boom and re-contextualisation of the classics of proletarian literature, like for example Kobayashi Takiji's 1929 novella Kani kōsen (The Crab Ship). In film, directors like Kurosawa Kiyoshi have gone beyond their favourite genres and adopted a neorealistic style reminiscent of the postwar period of political engagement and student unrest during the renewal of the security treaty between the United States and Japan in the 1960s. At the same time, even though films like Tokyo Sonata accurately portray the status quo of the struggling nuclear family, they romanticise the disenfranchised working class and individuals who are struggling to define themselves in Japan's postmodern consumer society.

Often, as is the case in Tokyo Sonata, the solution to Japan's social crisis is depicted in the individual's perseverance through hardship, no real alternative solutions are presented. The wife is still portrayed as the 
stereotypical "good wife, wise mother" (ryōsai kenbo), while the father retains his role as the family patriarch, and here too no alternative models of behaviour are acknowledged. The traditional morality of obedience and acquiescence is still portrayed as desirable in a society undergoing rapid transformation. Kurosawa does not attempt to show the alternative political legacy of left-wing politics in Japan with its tradition of emphasizing dissent, social mobility, and social conflict. In the end, Kurosawa's message is entertaining but somewhat disappointingly stereotypical: if you keep on believing and persevere, then something will happen. Yet nothing nice is going to happen if Japan and its citizens are not willing to become more proactive in changing the status quo. The political transition from the long-serving LDP to the relatively untested DPJ is promising evidence that change is on the horizon.

Roman Rosenbaum (roman.rosenbaum@sydney.edu.au) received his Ph.D. in Japanese literature at the University of Sydney. He specializes in postwar Japanese literature and popular cultural studies. In 2008 he received the Inoue Yasushi Award for best refereed journal article on Japanese literature in Australia. His latest co-edited book is entitled Legacies of the Asia-Pacific War: The "yakeato" generation and will be published by Routledge in 2010. Also in 2010 he spent a year as a research professor at the International Research Center for Japanese Studies (Nichibunken) to complete a monograph on the social activist Oda Makoto.

\section{Notes}

* I would like to particularly thank the two anonymous referees for their insightful suggestions to the content and structure of this manuscript.

1. The gap-widening society as defined by Yamada Masahiro divides Japanese society into either the winning or losing camps depending on whether they embrace a sense of aspirations or despair for the future. The term may also refer to a number of specific social factors like shakai-keizai kakusa [socio-economic disparity] or seikatsu-suijun kakusa [disparity in standards of living] that increasingly polarise contemporary Japanese society. For details see Yamada Masahiro (2004).

2. The abbreviation J-horror (Japanese horror) was coined in the 1980 s for the films of Tsuruta Norio, who instigated a shift from blood and guts visceral horror to more psychological intense atmospheric tension by showing less rather than more (McRoy 2007: 9).

3. Freeter $($ furīta $)$ is a neologism formed from the English word free and the German word Arbeiter (worker) and denotes a lack of full-time employment; the acronym NEET (Not in Employment, Education or Training) refers to unemployed and unmarried people who are not looking for work. Both terms point to the emergence of a generation of underprivileged youth whose future effect upon societies needs further investigation. 
4. The French nouvelle vague movement was created by filmmakers active from the late 1950s and 1960s, who were influenced by the portrayal of working-class conditions expressed in a neo-realistic style. Similarly, the Japanese New Wave movement explored the difficult economic and moral conditions of postwar Japan, describing the transformation of the Japanese psyche and everyday social conditions.

5. Arguably it was also in the late 1980s, with the first 16 chapters of Miyazaki Hayao's manga Kaze no tani no Naushika [Nausicaä of the valley of wind] made into a feature film of the same name in 1984 and Katsuhiro Otomo's release of Akira in 1988, that the shomin-geki tradition shifted from new-wave realism to allegorical representation in animated films.

6. Originating from shirakeru [to be bored or disenchanted], the term refers to a politically apathetic generation and conventionally applies to people born between 1955 and 1960, the generation that came of age after the student protests against the renewal of the security treaty.

7. Murakami Haruki in particular is at the literary forefront of a Japanese magic realism movement that interrogates the hegemony of the real over the imaginary and its relation to cosmopolitan capitalist consumer society.

\section{References}

Balmain, Colette. 2008. Introduction to Japanese horror films. Edinburgh: Edinburgh University Press.

Desser, David. 1988. Eros plus massacre: An introduction to the Japanese new wave cinema. Bloomington: Indiana University Press.

Erickson, Steve. 3 December 2009. Interview: Kiyoshi Kurosawa composes "Tokyo Sonata." Independent Film Channel. http://www.ifc.com/news/2009/03/kiyoshikurosawa.php (accessed 20 February 2010).

Guillén, Michael. 4 December 2008. Tokyo Sonata: The evening class interview. http:// theeveningclass.blogspot.com/2008/12/tokyo-sonata-evening-class-interview.html (accessed 20 February 2010).

Iles, Timothy. 2008. The crisis of identity in contemporary Japanese film: Personal, cultural. Leiden \& Boston: Brill.

Kaifu, Michi. 29 March 2009. Family and human nature, past and present, Tokyo and anywhere: "Tokyo Sonata" - Harsh reality and a light of hope. ENOTECH Consulting. http://www.hogacentral.com/Special_KK_TST.html (accessed 20 February 2010).

Kasman, Daniel. 17 October 2008. A conversation with Kiyoshi Kurosawa. The $A u$ teurs. http://www.theauteurs.com/notebook/posts/321 (accessed 20 February 2010).

Kurosawa, Kiyoshi. 1992. Eizō no karisuma: Kurosawa Kiyoshi eigashi [The charisma of the image: The cinematographic history of Kurosawa Kiyoshi]. Tokyo: Firumu Atosha.

Kurosawa, Kiyoshi. 2008. Tokyo Sonata. Tokyo: Django Film.

McDonald, Hamish. 29-30 August 2009. Japan set for a shock. Sydney Morning Herald. 3.

McRoy, Jay. 2007. Nightmare Japan: Contemporary Japanese horror cinema. Amsterdam \& New York: Rodopi.

Miura, Atsushi. 2005. Karyū shakai: Aratana kaisō shūdan no shutsugen [Low-class society: The appearance of a new class stratum]. Tokyo: Kōbunsha Shinsho.

Mottesheard, Ryan. 1 August 2001. Interview: Kurosawa's "cure" for the common horror film. IndieWIRE. http://www.indiewire.com/article/interview_kurosawas_ cure_for_the_common_horror_film (accessed 20 February 2010). 
O’Rourke, Jim. 2005. Kiyoshi Kurosawa: The artist's voice since 1981. Bomb Magazine 91. http://www.bombsite.com/issues/91/articles/2717 (accessed 20 February 2010).

Taubin, Amy. 2009. Weights and measures. Artforum 47 (7). 79.

Wakabayashi, Daisuke. 7 March 2009. Interview: Jobless in Tokyo - A Japanese director turns from thrills and chills to a tale of economic woe. The Wall Street Journal (Eastern edition). 2. http://online.wsj.com/article/SB123638486847658215. html (accessed 20 February 2010).

Yamada, Masahiro. 1999. Parasaito shinguru no jidai [The age of parasite singles]. Tokyo: Chikuma Shobo.

Yamada, Masahiro. 2004. Kibo kakusa shakai: "Makegumi” no zetsubokan ga Nihon o hikisaku [Society of expectation gaps: The despair of the "losers" is tearing up Japan]. Tokyo: Chikuma Shobo. 